Michat Tomczyk

Lucerna

\title{
AUSTRIA I SZWAJCARIA WOBEC UTWORZENIA JEDNOLITEGO RYNKU EUROPEJSKIEGO. ANALIZA PORÓWNAWCZA
}

Austrię i Szwajcarię łączy wiele podobieństw. Oba państwa nie tylko były członkami, ale również założycielami Europejskiej Wspólnoty Wolnego Handlu (EFTA). Polityka zagraniczna obu krajów determinowana jest doktryną neutralności, choć jej źródła i charakter pozostają odmienne. Oba cechuje podobna liczba mieszkańców i stosunkowo niewielka powierzchnia ${ }^{1}$. Gospodarki Szwajcarii i Austrii rozwijały się dynamicznie od lat 60. XX w. i były w ogromnym stopniu zależne od współpracy z państwami należącymi do $\mathrm{EWG}^{2}$. Oba państwa przeżywały również okres spowolnienia gospodarczego $\mathrm{w}$ latach 80 . XX w., który był jednym z ważniejszych czynników wpływających na decyzje złożeniu wniosku akcesyjnego do Wspólnot Europejskich ${ }^{3}$. Zarówno w przypadku Austrii jak i Szwajcarii członkostwo w strukturach europejskich łączono z problemem wspomnianej neutralności, choć jak pokazała praktyka, znaczenie tego argumentu, zarówno w debacie publicznej, jak i negocjacjach akcesyjnych było nieco odmienne. Powyższe podobieństwa nie sprawiły jednak, iż oba państwa zdecydowały się na taka samą formę integracji. Austria w 1995 roku stała się pełnoprawnym członkiem Wspólnoty, podczas gdy Szwajcaria nadal pozostaje poza jej strukturami i wszystko wskazuje na to, iż w najbliższym czasie nie należy oczekiwać większych zmian w tym względzie.

1 Austria liczy ok 8,5 mln mieszkańców, żyjących na powierzchni 83.878,99 km², podczas gdy Szwajcarię zamieszkuje 8 mln mieszkańców na powierzchni 41.285 km².

${ }_{2}$ W 1983 roku 53,7\% austriackiego eksportu trafiało do państw EWG, a zaledwie 11\% do państw EFTA. W 1989 roku wartości te wynosiły odpowiednio do 63,9\% oraz 10,6\%.

${ }_{3}$ Pod koniec lat 80. tych gospodarka Austrii nieco przyspieszyła, jednakże ocenia się, iż fakt ten miał niewielki wpływ na decyzję o przystąpieniu do EWG. Por. P. Luif, The evolution of EC-EFTA Relations and Austria's Integration Policy, [w:] H. Neuhold, The European Neutrals in the 1900s. New Challenges and Opportunities, Boulder 1992, s. 55-89. 
Warto prześledzić zatem rozwój relacji obu państw z WE, aby sprawdzić, jakie czynniki zadecydowały w największym stopniu o ich współczesnym wymiarze. Dlaczego tak podobne do siebie państwa wybrały inne drogi do integracji europejskiej? Aby odpowiedzieć na to pytanie należy przeanalizować główne uwarunkowania zewnętrze oraz wewnątrzpolityczne, które zadecydowały o wyborze określonej opcji integracyjnej. Analizą objęto w szczególności okres od połowy lat 80.tych, tj. od momentu podpisania Jednolitego Aktu Europejskiego, będącego podstawą utworzenia wspólnego rynku. Jest to niezwykle istotny etap w rozwoju WE, będący zarazem jednym z ważniejszym argumentów podjęcia aktywniejszych działań integracyjnych przez oba państwa. Niniejszy artykuł jest więc próbą nakreślenia, w perspektywie porównawczej, sytuacji politycznej i społecznej w Austrii oraz Szwajcarii, przy uwzględnieniu istniejących na przełomie lat 80. i 90. specyficznych uwarunkowań geopolitycznych.

\section{Austria w procesie integracji europejskiej}

Utworzenie wspólnego rynku było przełomowym punktem $\mathrm{w}$ relacjach Austrii z WE. Rząd wielkiej koalicji SPÖ oraz ÖVP podjął wówczas decyzję o rozpoczęciu działań w kierunku najpierw quasi (niepełnego) członkostwa, a następnie pełnego członkostwa we Wspólnocie ${ }^{4}$. Ta pierwsza forma integracji miała być kombinacją unilateralnych, multilateralnych i bilateralnych form współpracy i stopniowej adaptacji do regulacji obowiązujących na całym obszarze wspólnego rynku. Szczególnym przedmiotem troski rządu austriackiego był rynek rolny, który dotkliwie odczuwał protekcyjną politykę państw Wspólnoty. Ponadto, rząd zdawał sobie sprawę, iż tylko poprzez ścisłą współpracę, czy też pełną integrację będzie $\mathrm{w}$ stanie przeprowadzić konieczne reformy gospodarcze. W połowie lat 80 .tych sektor przemysłowy borykał się z wieloma problemami, wynikającymi w znacznej mierze z faktu, iż znakomita część dużych państwowych przedsiębiorstw była od wielu lat nierentowna ${ }^{5}$. Rząd miał nadzieję, iż przystąpienie do wspólnego rynku ułatwi procesy modernizacji i liberalizacji austriackiej gospodarki i pomoże jej ponownie nabrać rozpędu. Ponadto liczono na pełny dostęp do wspólnotowych programów badawczych i rozwojowych ${ }^{6}$.

${ }^{4}$ Por. H. Kremer, "Wende” in der österreichischen Aussenpolitik? Zur Aussenpolitik der SPÖ - ÖVP Koalition, Österreichische Zeitschrift für politische Wissenschaft, 1988(2), s. 117-131.

${ }^{5}$ P. Luif, On the Road to Brussels: The Political Dimension of Austria's, Finland's and Sweden's Accession to the European Union, Wilhelm Braumüller-Wien 1995, s. 122.

6 Außenpolitischer Bericht 1987, MANZsche Verlags- und Universitätsbuchhandlung-Wien 1988, s. 121-125. 
Nie bez znaczenia był również fakt, iż Austria przeżywała w owym czasie kryzys tożsamości, wywołany szeregiem skandali i afer (skandal winny, afera Redera, skandal Noricum, afera Lucona, afera Waldheima), które podważały naturalną przynależność kraju do europejskiej społeczności i wywołały międzynarodową dyskusję wokół nazistowskiej przeszłości Austrii i jej aktualnymi konsekwencjami. Integracja miała być zatem próbą ich przezwyciężenia ${ }^{7}$.

Pierwsze sygnały nowego kursu wobec WE pojawiły się w raporcie dotyczącym polityki zagranicznej z 1986 roku$^{8}$. Jednakże dopiero w dokumencie opublikowanym rok później można odnaleźć bardziej szczegółowe informacje, dotyczące strategii rządu w polityce europejskiej9. Zarówno w raportach rządowych jak i umowach koalicyjnych z 1987 roku (SPÖ oraz ÖVP) zawarte były jednoznaczne deklaracje na temat chęci przyłączenia Austrii do wspólnego rynku. Przewidywano, iż realizacja tego celu będzie możliwa poprzez wybór najbardziej optymalnego rozwiązania spośród dwóch zasadniczych opcji. Pierwsza zakładała autonomiczną adaptację wobec regulacji wspólnotowych (tzw. autonomer Nachvollzug). Oznacza ona dobrowolne dostosowanie austriackiego prawodawstwa do prawa wspólnotowego, celem osiągnięcia maksymalnie wysokiego

7 Skandal winny z 1985 r. wstrząsnął austriackim przemysłem winiarskim i doprowadził do drastycznych spadków sprzedaży i wywozu soku winogronowego. Niektórzy producenci wina wykorzystywali w produkcji glikol di-etylenowy, rodzaj oleistej alkoholu używanego jako środek przeciwko zamarzaniu. Walter Reder był członkiem austriackiego SS, skazanym na więzienie za zbrodnie wojenne. W 1985 roku został uwolniony z więzienia. Powitanie Redera i publiczne okazanie wsparcia przez ówczesnego ministra obrony Friedhelma Frischenschlagera wywołało międzynarodowy skandal, który zapoczątkował szerszą dyskusję nad nazistowską przeszłością Austrii. Skandalem zakończyła się również sprawa dostarczania broni przez firmę Noricum, należącą do państwowego giganta stalowego Vöest, do ogarniętych wojną Iraku i Iranu w 1980 roku. Afera Lucona związana była z próbą wyłudzenia wielomilionowego odszkodowania, w która zamieszanych było m.in. kilku prominentnych polityków austriackich (SPÖ), prawników oraz wyższych urzędników państwowych. Kurt Waldheim był sekretarzem generalnym ONZ w latach 19721981 oraz prezydentem federalnym Austrii w latach 1986-1992, podejrzewanym o udział w zbrodniach wojennych w okresie narodowego socjalizmu. W 1986 roku wyszło na jaw, iż przez lata ukrywał swoją przynależność do SA oraz służbę wojskową w latach 1943-44. Ujawnienie jego przeszłości przyczyniło się do częściowej alienacji Austrii na arenie międzynarodowej w okresie jego prezydentury, było powodem uznania jego osoby za persona non grata w wielu krajach świata (m.in. w USA).

${ }^{8}$ Por. Aussenpolitischer Bericht 1985, MANZsche Verlags- und Universitätsbuchhandlung, Wien 1986.

9 Raport z 1987 roku sprowokował intensywną debatę parlamentarną nad przyszłością polityki europejskiej. Szerzej na temat tej debaty zob. T. Schwendimann, Herausforderung Europa. Integrationspolitische Debatten in Österreich und in der Schweiz 1985-1989, Bern 1993, s. 122-124. 
stopnia unifikacji dorobku prawnego i eliminacji tym samym potencjalnych, legislacyjnych barier ${ }^{10}$. Powyższe miało być uzupełnione zawarciem umów bilateralnych pomiędzy Austrią a WE oraz na poziomie międzyinstytucjonalnym, tj. pomiędzy EFTA oraz Wspólnotą (sprzyjała temu deklaracja luksemburska, podpisana w 1984 roku w trakcie ministerialnego spotkania przedstawicieli EFTA oraz WE) ${ }^{11}$. Druga opcja zakładała pełne członkostwo Austrii we Wspólnocie ${ }^{12}$. Wybór jednej z powyższych nie był łatwy, albowiem zależał od wielu wewnętrznych i zewnętrznych uwarunkowań. Warto zatem pokrótce je scharakteryzować.

Rząd, określając swoją strategię polityczną wobec Wspólnoty nie mógł działać w sposób niezależny. Po pierwsze, musiał wziąć pod uwagę stanowisko partnerów społecznych, którzy mieli możliwość silnego oddziaływania na procesy decyzyjne. Podobnie jak w przypadku Szwajcarii należałoby zaliczyć do tej grupy przede wszystkim środowiska gospodarcze - związki i stowarzyszenia pracodawców oraz pracobiorców (Österreichischer Arbeiterkammertag, Österreichischer Gewerkschaftsbund, Presidentenkonferenz der Landwirtschaftskammern), którzy dysponowali dużym zapleczem finansowym oraz kadrowym. Warto bowiem zauważyć, iż decydenci polityczni skazani są $w$ takich wypadkach na podejmowanie decyzji nijako na dwóch poziomach (two level games), uwzględniając interesy państwowe i uwarunkowania wewnątrzpolityczne (w tym własną polityczną przyszłość). Stanowisko partnerów społecznych miało zatem kluczowe znaczenie dla rządu austriackiego, który wstrzymywał się z prezentowaniem jednoznacznego stanowiska wobec opcji integracyjnych do momentu uzyskania jasnych przesłanek, co do poparcia jednego z rozwiązań przez innych, kluczowych aktorów procesu decyzyjnego.

Opcja pełnego włączenia Austrii do wspólnego rynku wydawała się dla rządu korzystniejsza, z uwagi na konieczną przy tej okazji do przeprowadzenia deregulację i liberalizację rynku, co było jednym z ważniejszych celów kanclerza Vranitzkiego ${ }^{13}$. Dwie główne przeszkody stały na drodze

${ }^{10} \mathrm{~W}$ takim przypadku mamy do czynienia ze zjawiskiem bezpośredniej internacjonalizacji, jako istotnego czynnika wpływającego na kształt procesów decyzyjnych. Szerzej na ten temat zob. A. Fischer, Die Auswirkungen der Internationalisierung und Europäisierung auf Schweizer Entscheidungsprozesse, Zürich 2005.

${ }^{11} \mathrm{~W}$ dokumencie tym potwierdzano chęć wzmocnienia i rozszerzenia współpracy w celu stworzenia „dynamicznej europejskiej przestrzeni gospodarczej”, Zob. szerzej na ten temat F. Laursen, The Community's Policy Towards EFTA: Regime Formation in the European Economic Space (EES), "Journal of Common Market Studies" 28(4), s. 303-325.

12 Por. C. Schaller, Die innenpolitische EG-Diskussion seit den 80-er Jahren, [w:] A. Pelinka, EU-Referendum. Zur Praxis direkter Demokratie in Österreich, Wien 1994, s. 60-71.

${ }_{13}$ Por. A. Pelinka, Europäische Integration und politische Kultur, [w:] A Pelinka, C. Schaller, P. Luif, Ausweg EG? Innenpolitische Motive einer aussenpolitischen Umorientierung, Wien 1994, s. 17. 
wyboru takiego rozwiązania. Pierwszą był brak jednomyślności odnośnie polityki europejskiej wśród rządowych ośrodków decyzyjnych. Podczas gdy ludowcy jednoznacznie opowiadali się za pełnym członkostwem we Wspólnocie, w łonie SPÖ brakowało jednomyślności ${ }^{14}$. Dlatego też, jeszcze do końca 1988 roku, rząd oficjalnie nie wypowiadał się w sposób jednoznaczny odnośnie perspektyw integracyjnych, choć wskazywały już na taki wybór wypowiedzi czołowych polityków obu obozów politycznych. Kanclerza Vranitzkiego, który jednakże z uwagi na brak poparcia wśród partyjnej bazy długo wstrzymywał się z prezentowaniem własnego stanowiska oraz Aloisa Mocka, szefa austriackiej dyplomacji ${ }^{15}$.

Drugą była niechęć części środowisk gospodarczych wobec perspektywy pełnej integracji ze Wspólnotą. Głównie ze strony sektora rolnego - obawiającego się negatywnego wpływu na rodzimy rynek oraz związki zawodowe, które bały się przede wszystkim utraty miejsc pracy.

Dlatego też rząd początkowo popierał opcję częściowego włączenia Austrii do wspólnego rynku, ponieważ tylko takiemu rozwiązaniu sprzyjały nastroje społeczne. Dopiero w momencie pojawiania się coraz częstszych przesłanek, dotyczących możliwego poparcia pełnej opcji integracyjnej przez najważniejszych partnerów społecznych, zdecydowano się na dokonanie odważniejszych zmian w strategii politycznej.

Wybór ostatecznej opcji integracyjnej uwarunkowany był również istotnymi czynnikami zewnątrz politycznymi. Należy podkreślić, iż doktryna neutralności Austrii miała zupełnie inne źródła niż w przypadku Szwajcarii, albowiem wynikała przede wszystkim z geopolitycznej konstelacji i była jednym $z$ elementów politycznej równowagi sił pomiędzy światowymi mocarstwami w okresie zimnej wojny ${ }^{16}$. Zgoda ZSRR na niepodległość Austrii, przypieczętowana traktatem państwowym z 1955 roku, możliwa była jedynie dzięki zagwarantowaniu całkowitej neutralności. Efektem czego jej aktywność międzynarodowa była w oczywistym stopniu ograniczona, a wszelkie działania zewnętrzne uzależniano w dużym stopniu od stanowiska władz na Kremlu. Dlatego też przez długie lata dyplomacja austriacka ograniczała się do tzw. dobrych usług, konkurując przy tym zresztą ze Szwajcarią. Wiedeń stał się stolicą

${ }^{14} \mathrm{Z}$ uwagi na negatywne stanowisko młodzieżówki socjalistycznej.

${ }^{15}$ Kanclerz Vranitzky po raz pierwszy opowiedział się publicznie za pełną integracją podczas jednego z sympozjów, organizowanych przez przemysł austriacki w październiku 1988 roku. Alois Mock przedstawił swoje stanowisko przy okazji debaty parlamentarnej nad rządowym raportem dot. polityki zagranicznej, która odbyła się w maju tego samego roku.

16 Szerzej na ten temat zob. D. Popławski, Austriacka polityka neutralności 1955-1995, Warszawa 1995. 
światowej dyplomacji, prześcigając w pewnym okresie pod tym względem nawet Genewę.

$\mathrm{Z}$ tego też powodu rząd austriacki musiał zachowywać wstrzemięźliwość w kwestiach integracyjnych, tym bardziej, iż rząd w Moskwie postrzegał EWG jako organizację $\mathrm{w}$ dużej mierze polityczną ${ }^{17}$. Sprzeciwiano się zatem włączeniu Austrii do jej struktur, oficjalnie stojąc na stanowisku, iż pozostaje to niemożliwe do pogodzenia z doktryną neutralności. Dopiero zmiany kierownictwa politycznego na Kremlu w postaci wyboru Michaiła Gorbaczowa na pierwszego sekretarza KC przyniosły nadzieję także na odwilż $w$ relacjach międzynarodowych ${ }^{18}$. Bez wątpienia proces ten również wpłynął na zmianę strategii politycznej rządu austriackiego wobec WE.

Drugim, niemniej istotnym elementem było stanowisko Wspólnot Europejskich wobec przyszłego kształtu współpracy z Austrią. Współpraca a la carte, a więc niepełne członkostwo było rozwiązaniem po części korzystnym dla Wspólnoty. Świeżo utworzony wspólny rynek wymagał nakładu wielu środków i dużego wysiłku ze strony obecnych 12 członków Wspólnoty, co uważano zresztą za aktualny priorytet w procesie integracji europejskiej ${ }^{19}$. Rozszerzenie było traktowane jako zadanie na później, choć oczywiście perspektywa ta nie mogła być bardzo daleka. Niemniej jednak zdawano sobie sprawę, iż podejmowanie decyzji i osiąganie kompromisu w szerszym gronie będzie siłą rzeczy trudniejsze. Z drugiej strony odmowa przyłączenia Austrii do WE mogłaby dać bardzo zniechęcający sygnał innym, potencjalnym kandydatom do członkostwa. Głównie pozostałym krajom EFTA, a w dalszej perspektywie również państwom Europy Środkowo-Wschodniej.

Wysunięto zatem propozycję rozwiązania pośredniego, z którą zwrócono się zarówno do rządu austriackiego jak i szwajcarskiego. Jacques Delor zaproponował stworzenie szerszych struktur współpracy poprzez włączenie obu państw do Europejskiego Obszaru Gospodarczego. Miano nadzieję, iż propozycja ta spotka się z pozytywnym odzewem ze strony Austrii i Szwajcarii. Oba kraje będą miały bowiem zagwarantowany dostęp do wspólnego rynku, jednakże bez możliwości oddziaływania na proces decyzyjny w ramach Wspólnoty, co dałoby

17 Eduard Szewardnadze określił WE jako polityczną organizację, mającą jednak wiele militarnych aspektów.

${ }^{18}$ Jak wskazuje P. Luif strategia ZSRR opierała się wówczas po części na założeniu, iż członkostwo państwa neutralnego daje szanse na opóźnienie procesu integracji Europy Zachodniej.

19 Zob. wypowiedź byłego komisarza europejskiego ds stosunków zewnętrznych Willy de Clerqa podczas szczytu EFTA-EC w Interlaken (Szwajcaria) w maju 1987 roku. 
czas na instytucjonalne przygotowanie do ewentualnego rozszerzenia w przyszłości. W praktyce inicjatywa spotkała się z niejednolitą reakcją. Podczas gdy stanowisko rządu szwajcarskiego wobec takiego rozwiązania było bardzo przychylne, głównie z uwagi na wewnątrzpolityczne, specyficzne uwarunkowania, o czym szerzej jeszcze w dalszej części tekstu, władze Austrii dały jasno do zrozumienia, iż propozycja ta nie wpłynie $\mathrm{w}$ większym stopniu na podjętą w międzyczasie decyzję o pełnym przystąpieniu do WE ${ }^{20}$. EOG może być co najwyżej traktowany jako przystanek na drodze do pełnej integracji, czemu dano dowód składając wniosek akcesyjny 17 lipca 1989 roku.

Ta ostatnia decyzja była zresztą możliwa z uwagi na krystalizujący się społeczny i wewnątrzpolityczny konsensus w sprawie przyłączenia Austrii do Wspólnoty. Punktem kulminacyjnym tego procesu było przedstawienie wspólnego oświadczenia partnerów społecznych, w marcu 1989 roku, w którym domagano się nawiązania ścisłych relacji ze Wspólnotą ${ }^{21}$. Na zmianę stanowiska najbardziej sceptycznie nastawionych do tego pomysłu środowisk wpływ miał między innymi raport przedstawiony przez specjalną grupę roboczą (Arbeitsgruppe für Europäische Integration), który zawierał argumentację, iż wszelkie, pośrednie formy członkostwa we Wspólnocie oznaczają brak możliwości faktycznego oddziaływania na procesy decyzyjne na poziomie europejskim, które mają w praktyce również ogromny wpływ na Austrię. EOG nie stanowi w tym względzie wyjątku. Stwierdzono zatem, iż ewentualne korzyści ekonomiczne, wynikające z samego przystąpienia do Europejskiego Obszaru Gospodarczego, nie są w stanie zrekompensować ewidentnych strat politycznych.

Także neutralność przestała być traktowana jako istotny argument w debacie nad przystąpieniem do Wspólnoty. Propozycja złożenia wniosku akcesyjnego została przegłosowana w Parlamencie znaczącą większością głosów - 175 na 183. Co ważne, ustalono, iż wniosek będzie zawierał zastrzeżenie dotyczące uszanowania neutralnego statusu Austrii, które miało zagwarantować jej możliwość przestrzegania zobowiązań prawnych, zawartych w konstytucji. Ten istotny punkt przyjęty został ze zrozumieniem przez Radę Ministrów Wspólnot oraz Komisję Europejską. Uwarunkowania wewnątrz- i zewnątrzpolityczne umożliwiły zatem Austrii przystąpienie do Unii Europejskiej w 1995 roku, razem z dwoma innymi państwami prowadzącymi politykę neutralności - Szwecją i Finlandią.

20 C. Schaller, op. cit., s. 112.

21 Zob. T. Schwendimann, op. cit., 153-154. 


\section{Szwajcarska droga do integracji}

Pomimo wspomnianych na samym początku artykułu podobnych uwarunkowań ekonomicznych i politycznych pomiędzy Austrią a Szwajcaria, polityka zagraniczna tej ostatniej determinowana była w znacznie większym stopniu przez doktrynę neutralności. Po części wynikało to z faktu, iż jej status nie był efektem bipolarnej równowagi sił, lecz pozostawał głęboko zakorzeniony w historii i tradycji szwajcarskiej państwowości ${ }^{22}$. Ponadto neutralność była skutecznym instrumentem ochrony interesów politycznych i ekonomicznych Szwajcarii, która sprawdziła się doskonale, zarówno w pierwszej jak i drugiej wojnie światowej, a także w okresie powojennym, naznaczonym zimnowojennymi napięciami. Nic więc dziwnego, iż perspektywa zmiany strategii politycznej nie wywoływała entuzjazmu, zarówno wśród decydentów politycznych jak i większości opinii publicznej. Tym bardziej, iż swoista konsekwencja w tym względzie wynikała z subiektywnie postrzeganej odrębności Szwajcarii, tzw. Sonderfall (szczególny przypadek), silnie zakorzenionej w mentalności jej mieszkańców. Usprawiedliwiano dzięki niej pewną alienację państwa i jego stosunek wobec otaczającej rzeczywistości. Do pewnego stopnia starano się także wykorzystywać tę „wyjątkowość" do wytłumaczenia negatywnego stosunku wobec szerszej integracji europejskiej.

Procesy integracyjne zmusiły jednak Szwajcarię do zredefiniowania przyjętej doktryny, efektem czego zrezygnowano ze sztywnej interpretacji doktryny Bindschedlera z 1954 roku $^{23}$. W rezultacie Szwajcaria została członkiem założycielem EFTA w 1961 roku, a także podpisała układ o wolnym handlu z EWG. Władze starały się jednak nadal przestrzegać, zawartego we wspomnianej doktrynie, podziału organizacji o charakterze politycznym i technicznym, kategorycznie odrzucając członkostwo w tych pierwszych.

Warto również w tym miejscu nadmienić, iż przez lata polityka zagraniczna, przynajmniej w porównaniu do państw ościennych, spełniała rolę raczej marginalną, oddając prym polityce wewnętrznej. Te dwie sfery były

${ }^{22}$ D. Popławski, Szwajcarska polityka...,s. 46-75.

${ }^{23}$ W 1954 roku opublikowano oficjalną koncepcję neutralności, zwaną później doktryną Bindschedlera. Treść dokumentu dostępna jest w bazie DoDiS (Diplomatische Dokumente der Schweiz), pod adresem: http://www.dodis.bar.admin.ch/dodis/dodis;jsessionid=f43038f7021d4c86e458?XE7lhitk5AZh7Dfw9OYVZZzghtrLw7sN7xvmXB5111irfjtWjzj7ogT7P4OQr2JQy9Qemj0KNJEQOhR9qYpv45a; dodis.ch/9565, (16.09.2009); Por. D. Popławski, op. cit., s. 80 oraz D. Schindler, Dokumente zur schweizerischen Neutralität seit 1945: Geschichte und Stellungnahme der schweizerische Neutralität seit 1945-1983, Bern-Stuttgart 1984. 
ponadto traktowane jako dwa, wręcz niezależne od siebie byty. Miało to swoje odzwierciedlenie, tak na poziomie instytucjonalnym, jak i intelektualnym, o czym świadczyć może chociażby brak długofalowych strategii, opartych na głębszych refleksjach politycznych ${ }^{24}$.

Analizując motywy, dla których rząd Szwajcarii zaczął zabiegać o współpracę ze Wspólnota, wskazać należy na trzy główne czynniki. Po pierwsze, kierował się względami ekonomicznymi. Szwajcarska gospodarka zależna jest od wymiany handlowej z innymi państwami, albowiem rynek wewnętrzny nie jest wystarczająco chłonny, aby móc zapewnić jej stabilny rozwój. Poza sektorem bankowym to właśnie eksport stanowi główną gałąź, na której opiera się PKB. Istotne znaczenie mają również bezpośrednie inwestycje zagraniczne. Szwajcarskie przedsiębiorstwa tworzą tysiące miejsc pracy za granicą. Wiele zagranicznych firm ulokowanych jest również w Szwajcarii. Jednakże, co istotne, głównym partnerem handlowym i gospodarczym pozostawała Europa, w tym przede wszystkim państwa należące do Europejskiej Wspólnoty Gospodarczej. Żywotne znaczenie miało zatem zapewnienie korzystnych warunków współpracy z krajami EWG, głównie poprzez likwidację barier w handlu. Problemem, podobnie jak w przypadku Austrii, była protekcjonistyczna polityka, stosowana przez Wspólnotę wobec państw, niebędących jej członkami.

Rozwiązaniem powyższych bolączek miała być EFTA, której zasady działania odpowiadały przyjętym przez Szwajcarię kryteriom współpracy multilateralnej. Była ona bowiem organizacją o charakterze czysto gospodarczym, mającą na celu wyłącznie eliminację barier w handlu, na czym rządowi szwajcarskiego najbardziej zależało. EFTA spełniania zatem kryteria organizacji o charakterze technicznym. Uznano zatem, iż współpraca $\mathrm{w}$ ramach strefy wolnego handlu nie była sprzeczna z neutralnością. Dość szybko kraje EFTA stały się najważniejszym partnerem handlowym Szwajcarii.

Wkrótce okazało się jednakże, iż współpraca oparta wyłącznie na zniesieniu barier handlowych nie rozwiązuje wszystkich problemów. Bardzo szybko zaczęli zauważać to inni członkowie EFTA, decydując się, jeszcze pod koniec lat '60, na nawiązanie ściślejszej współpracy z Europejską Wspólnotą Gospodarczą.

W ten sposób dochodzimy do drugiego czynnika dążeń integracyjnych, wynikających ze słabości Europejskiej Strefy Wolnego Handlu. Rząd szwajcarski zdawał sobie sprawę, iż malejąca liczba członków odbija się zarówno na ekonomicznej efektywności jak i politycznym znaczeniu całej organizacji. W tej sytuacji rozważany przez szwajcarskie władze wariant

${ }^{24}$ M. Tomczyk, Polityka Szwajcarii wobec Unii Europejskiej, Łódź 2013, s. 21. 
nawiązania międzyinstytucjonalnej współpracy EFTA-EWG, z uwagi na słabość tej pierwszej jest mało realny. EFTA nie mogła być równym partnerem w ewentualnych negocjacjach. Współpraca na tym poziomie nie stanowi również odpowiedzi na coraz częściej pojawiające się problemy natury politycznej, związane chociażby z procesami decyzyjnymi $\mathrm{w}$ ramach Wspólnoty, a mającymi ogromne znaczenie również dla państw niewchodzących w jej skład.

Ostatnia kwestia, o której warto wspomnieć związana jest z szerszą wizją roli i miejsca Szwajcarii w integrującej się Europie. Rząd w Bernie zaczął zdawać sobie sprawę z szerszego kontekstu integracji, której nie można traktować w kategoriach czysto instytucjonalnych. Chęć zawarcia pragmatycznych układów handlowych zastąpiona została z czasem dążeniem do nawiązania współpracy na nowych płaszczyznach, pozwalających na pełnoprawne włączenie Szwajcarii do europejskiej rodziny, a co za tym idzie, oddalenie groźby politycznej, gospodarczej czy nawet kulturowej izolacji ${ }^{25}$.

Podsumowując można zatem stwierdzić, iż druga połowa XX wieku naznaczona była przejściem od polityki koegzystencji, będącej domeną lat powojennych, do polityki kooperacji, a więc otwarcia władz Szwajcarii na szerszą współpracę międzynarodową ${ }^{26}$. WE stała się naturalnym i najważniejszym partnerem dla Szwajcarii. Istotny był tutaj nie tylko aspekt geograficzny czy gospodarczy ${ }^{27}$, lecz także poczucie pewnej więzi, opartej na spójnych celach i przyjętych strategiach rozwoju. Dotyczy to również wsparcia i promocji pokoju oraz praw człowieka. Wartości, które stały się podstawą funkcjonowania Wspólnoty i które w polityce państwa neutralnego odgrywają niezwykle istotną rolę ${ }^{28}$.

Podobnie jak w przypadku Austrii rząd szwajcarski rozważał kilka dróg integracyjnych, sondując przy tym aktualne nastroje społeczne i debatę prowadzoną na forum parlamentu. Rozważano zatem opcję pełnej integracji oraz a la carte, opartej na umowach dwustronnych. W tym punkcie

${ }^{25}$ Obserwując debatę związaną z tym tematem, bardzo często spotkać można się z opiniami mówiącymi o silnej obawie przed określeniem Szwajcarii jako kulturowego kopciuszka Europy. Por. M. Schenker, EG als Chance. Die Schweiz am europäischen Scheideweg, Werd Verlag, Zürich 1991, s. 21.

${ }^{26}$ D. Thürer, Aussenpolitische Aspekte der künftigen Beziehung zur Europäischen Gemeinschaft, [w:] A. Riklin, H. Hans, R. Probst, Neues Handbuch der schweizerischen Aussenpolitik, Verlag Paul Haupt, Bern 1992, s. 534.

${ }_{27}$ Zob. L. Goetschel, M. Bernath, D. Schwarz, Schweizerische Aussenpolitik. Grundlagen und Möglichkeiten, Verlag Neue Zürcher Zeitung, Zürich 2002, s. 166-172.

28 O zbieżności celów i strategii rozwoju mówił Raport 1993 oraz Raport z 1999 dot. integracji europejskiej: Schweiz - Europäische Union: Integrationsbericht 1999, EDMZ, Bern 1999, s. 207. 
widzimy zatem dużą zbieżność ze strategią rządu austriackiego. Trzecia droga - izolacjonizm, obecny był co prawda w dyskusji, jednakże nie był poważnie brany pod uwagę. Pojawiające się coraz częściej w parlamencie głosy dotyczące konieczności przeciwdziałania negatywnym praktykom dyskryminacyjnym wobec szwajcarskich firm oraz towarów na rynkach wspólnotowych zachęciły rząd do przedstawienia pierwszego raportu na temat możliwych strategii w polityce europejskiej29.

Dokument zaprezentowany w 1988 roku zawierał zatem wspomniane wyżej opcje integracyjne, przy czym pozostawiał otwartą furtkę co do jednoznacznego wyboru jednej z nich. Toczące się wówczas debaty $\mathrm{w}$ parlamencie wskazywały jednakże, iż na większe poparcie liczyć mogły rozwiązania, oparte na dwustronnych, sektorowych umowach. Część ugrupowań politycznych nie odrzucała kategorycznie opcji pełnego członkostwa. Obawiano się jednakże, iż takie rozwiązanie naraziłoby szwajcarską gospodarkę na zbyt dużą presję, a także stanowiłoby poważne zagrożenie dla politycznej autonomii. Poza tym sporą uwage przywiązywano również do statusu neutralności, który postrzegano jako niekompatybilny z członkostwem we Wspólnocie ${ }^{30}$. W dokumencie podkreślano jednak, iż istotnym elementem nowej strategii musi być konieczność zagwarantowania Szwajcarii możliwości współdecydowania w kwestiach europejskich.

Osiągnięcie tego ostatniego elementu nie mogło być możliwe z poziomu rozwiązań międzyinstytucjonalnych lub bilateralnych, z czego rząd doskonale zdawał sobie sprawę. Dwa czynniki miały tutaj jednak szczególnie istotne znaczenie. Z jednej strony, część państw należących do WE z niechęcią odnosiła się do perspektywy tworzenia specjalnych przywilejów dla państw niebędących członkami Wspólnoty. Z drugiej, rząd szwajcarski nie mógł liczyć na wsparcie swoich dążeń integracyjnych, na jakie mógł liczyć jego austriacki odpowiednik. Cześć partii była gotowa poprzeć taki projekt, oczywiście pod pewnymi warunkami, jednakże stanowisko eurosceptycznie nastawionych ludowców uniemożliwiało osiągniecie potrzebnej większości.

${ }^{29}$ Decydujące znaczenie w tym kontekście miał postulat zgłoszony przez Komisję ds. Gospodarczych i opodatkowania izby niższej parlamentu w lutym 1987 roku. Komisja domagała się przedstawienia przez rząd sprawozdania na temat pozycji międzynarodowej Szwajcarii, w związku z postępującą integracją europejską (w perspektywie wejścia w życie jednolitego aktu europejskiego oraz ustanowienia wspólnego rynku). Zob. Die Schweiz und die europäische Integration, Postulat der Kommission für Wirtschaft und Abgaben NR, Ad 87.005-1, http://www.parlament.ch/afs/data/d/gesch/1987/d_gesch_1987005-1_002.ht$\mathrm{m} \#$ top (14.01.2014).

${ }_{30}$ C. Dupont, P. Sciarini, D. Lutterbeck, Catching the EC Train. Austria and Switzerland in Comparative Perspective, European Journal of International Relations, London 1999, s. 205. 
W tej sytuacji zdecydowano się na rozwiązanie pośrednie, zaproponowane przez Delora. Włączenie Szwajcarii do EOG miało być instrumentem zapewniającym duże korzyści ekonomiczne przy relatywnie wysokich politycznych. Rząd miał nadzieję, iż dzięki takiej formie współpracy uda się zagwarantować przynajmniej częściowy dostęp do procesów decyzyjnych na poziomie europejskim. Miał to być zatem sposób na integrację a la carte. Ta strategia okazała się jednakże nieskuteczna, o czym rząd przekonał się dosyć szybko podczas negocjacji w sprawie EOG.

Wobec braku możliwości osiągnięcia celów politycznych, władze w Bernie zdecydowały się na podjęcie bardzo ryzykownego kroku. Pomimo braku parlamentarnej większości uznano, iż przystąpienie do Wspólnoty będzie celem strategicznym rządu. Członkostwo w EOG miało być traktowane jako pierwszy etap na drodze do pełnej integracji, gdyż tylko taka forma współpracy zabezpiecza $\mathrm{w}$ wystarczającym stopniu interesy ekonomiczne i polityczne Szwajcarii ${ }^{31}$. Widać zatem wiele zbieżności w tym względzie ze stanowiskiem rządu austriackiego.

Nową strategię przedstawiono w raporcie opublikowanym w maju 1992 roku, a więc jeszcze przed głosowaniem nad przystąpieniem do Europejskiego Obszaru Gospodarczego. Warto wskazać motywy, dla których podjęto taką decyzję. Bez wątpienia jedną z nich była perspektywa przystąpienie innych krajów neutralnych do Wspólnoty. Wniosek akcesyjny złożyła już w tym czasie Austria, Szwecja i Finlandia. Decyzja państw EFTA oznaczała zatem dalsze osłabienie tej organizacji, a co za tym idzie również słabszą pozycję negocjacyjną Szwajcarii. Precedens neutralnej Austrii mógł również odebrać istotny argument związany $\mathrm{z}$ neutralnością. Ewentualne postulaty, zgłaszane $\mathrm{w}$ tym temacie przez rząd szwajcarski, dawno straciłyby na aktualności. Zmiana strategii integracyjnej podyktowana była także szczytem $\mathrm{w}$ Maastricht $\mathrm{z}$ grudnia 1991. Władze w Bernie uznały, iż jest to najlepszy moment, aby dzięki decyzji o włączeniu Szwajcarii zagwarantować sobie możliwość współkształtowania tej organizacji zwłaszcza w tych aspektach, które nie zostały jeszcze całkowicie zdefiniowane ${ }^{32}$. Ponad to zbliżające się rozszerzenie Wspólnoty oznacza konieczność przeprowadzenia stosownych reform instytucjonalnych, co automatycznie oddali perspektywę przyjęcia kolejnych członków. Rząd w Bernie obawiał się zatem, że jeżeli Szwajcaria nie zdecyduje się na przyłączenie do Wspólnoty w obecnej „rundzie”, na kolejną przyjdzie czekać kilka ładnych lat. Tym samym na możliwość

31 Przystąpienie do Europejskiego Obszaru Gospodarczego oznacza konieczność ujednolicenia określonych podstaw prawnych, a więc przyjęcia przynajmniej części acquis communautaire. EOG stwarza zatem warunki ramowe dla przyszłej integracji.

32 Bericht über einen Beitritt..., s. 7. 
współdecydowania o politycznym kształcie tej organizacji będzie już za późno.

Istotne były również uwarunkowania wewnątrzpolityczne. Publikacja raportu przed głosowaniem w sprawie EOG miała kapitalne znaczenie z punktu widzenia społecznej legitymizacji polityki europejskiej rządu. Opowiadając się za przystapieniem do Europejskiego Obszaru Gospodarczego obywatele dawaliby wyraz poparcia nowo przyjętej strategii. Taki wariant bez wątpienia osłabiłby pozycję ugrupowań eurosceptycznych i konserwatywnych w parlamencie i dałby nadzieję na pozytywny przebieg całego procesu decyzyjnego dotyczącego przyszłego wniosku akcesyjnego. Nie bez znaczenia był również fakt, iż publikacja raportu nadawała głosowaniu większej transparentności, informując obywateli o prawdziwych intencjach i strategii rządu na najbliższe lata.

Społeczeństwo odebrało jednak powyższe działania negatywnie, uznając decyzję o przystąpieniu Szwajcarii do UE za przedwczesna, czemu dano wyraz w trakcie głosowanie w sprawie EOG w grudniu 1992 roku. Przeprowadzone wówczas referendum zakończyło się fiaskiem, zmuszając tym samym rząd do ponownego zredefiniowania celów w polityce europejskiej ${ }^{33}$. Władze w Bernie zostały zmuszone do powrotu do koncepcji integracji poprzez porozumienia dwustronne ${ }^{34}$. Już w lutym 1993 roku zaproponowano UE podjęcie rozmów w 15 obszarach tematycznych. Należy $\mathrm{w}$ tym miejscu podkreślić, iż z inicjatywą nawiązania współpracy bilateralnej wyszła Szwajcaria. Początkowe stanowisko Unii Europejskiej było raczej niechętne. Uważano tego typu formę współpracy za przestarzała, nieodpowiadającą nowym wyzwaniom globalizacyjnym ${ }^{35}$. Ostatecznie jednak Rada UE ustosunkowała się przychylnie wobec propozycji Szwajcarii, zatwierdzając siedem obszarów negocjacyjnych ${ }^{36}$. Zakończyły się one podpisaniem pierwszego pakietu porozumień w 1999 roku.

33 Przy wysokiej frekwencji, sięgającej 79\% niewielka większość obywateli - 50,3\% opowiedziała się przeciwko włączeniu Szwajcarii do EOG (w tym 14 kantonów i 4 półkantony). Za było 49,7\%. Odrzucenie wniosku dot. przystąpienia do EOG wzmocniło natomiast ugrupowania konserwatywne, które pozyskały wśród obywateli wielu nowych zwolenników. Świadomość szerokiego poparcia dla reprezentowanych poglądów sprzyjała rozwojowi i dawała asumpt do śmielszych i energiczniejszych działań (w tym m.in. antyunijnych kampanii). Z biegiem czasu takie partie, jak ludowo-konserwatywna SVP, zyskiwały coraz większy wpływ na kształtowanie kierunków politycznych państwa na następne lata.

${ }_{34}$ W styczniu 1993 roku Rada Związkowa wydała komunikat o zamrożeniu wniosku akcesyjnego i rezygnacji z rozpoczęcia negocjacji z UE.

35 G. Kreis, Ein langer Weg In Etappen, [w:] Schweiz - Europa: wie weiter? Kontrollierte Personenfreizügigkeit, pod red., G. Kreis, Verlag Neue Zürcher Zeitung, Zürich 2009, s. 22.

36 Oficjalne negocjacje rozpoczęły się w grudniu 1994 roku. 


\section{Podsumowanie}

W niniejszym artykule przeanalizowana została, w ujęciu porównawczym, polityka dwóch, pod wieloma względami zbliżonych do siebie, neutralnych państw wobec WE, ze szczególnym uwzględnieniem okresu po podpisaniu Jednolitego Aktu Europejskiego, stanowiącego normatywną podstawę ustanowienia wspólnego rynku. Wykazano, iż pomimo zbieżnych celów politycznych i ekonomicznych, władze Austrii i Szwajcarii kierowały się innymi przesłankami podejmując decyzję o wyborze najbardziej optymalnej formy integracji z UE. Rząd austriacki działał w sprzyjających okolicznościach, zarówno wewnątrzpolitycznych jak geopolitycznych, które umożliwiły, po początkowych trudnościach, członkostwo we Wspólnocie. Władze wybrały zatem taką formę współpracy, która była w pełni koherentna ze stanowiskiem państw Wspólnoty, a przy tym odpowiadała społecznym oczekiwaniom. Choć istotnym elementem jest tutaj fakt, iż rząd znacznie wcześniej opowiedział się za pełną integracją dając sobie tym samym więcej czasu na uzyskanie społecznej legitymizacji dla własnych działań. $W$ tym punkcie widzimy zatem zasadniczą różnicę między austriacką a szwajcarską strategią wobec państw Wspólnoty. Dla Austrii integracja była niezwykle ważnym krokiem, zarówno ze względów ekonomicznych - restrukturyzacja krajowej gospodarki, zniesienie barier handlowych $\mathrm{z}$ najważniejszym partnerem gospodarczym, jak i politycznym, zapewniając możliwość współkształtowania procesów decyzyjnych na poziomie europejskim. Nie bez znaczenia był również fakt, iż członkostwo w Unii Europejskiej pozwoliło również poprawić nadszarpnięty licznymi skandalami i aferami wizerunek międzynarodowy. Przyłączenie Austrii i innych państw neutralnych bądź prowadzących politykę neutralności stworzyło precedens, który może być wykorzystany w debacie nad ewentualna, pełną integrację Szwajcarii z UE.

W przeciwieństwie do rządu austriackiego władze w Bernie działały w zdecydowanie bardziej spolaryzowanych uwarunkowaniach. Kwestia członkostwa we Wspólnocie nie cieszyła się społecznym poparciem, jak miało to miejsce w przypadku Austrii. Znacznie większą rolę odgrywała tutaj kwestia neutralności. Obawiano się także całkowitego otwarcia rynku oraz politycznego uzależnienia od ponadnarodowej instytucji. Częściowa utrata suwerenności była jednym z częściej podnoszonych argumentów w debacie publicznej. Dodatkowo niekorzystnym posunięciem było zbyt późne informowanie społeczeństwa o zmianach w przyjętej strategii, tj. zamiarze włączenia Szwajcarii do Unii Europejskiej. Wydany przez rząd komunikat, w którym podjęto próbę uzasadnienia swoich działań okazał się niewystarczający. W ten sposób władze zmuszone były do powro- 
tu do idei powiązań bilateralnych, które co prawda nie były koherentne ze stanowiskiem państw UE, ale dalece bardziej akceptowalne społecznie, a przez to zdecydowanie bardziej realne. Co ważne jednak, rząd nie porzucił całkowicie opcji pełnej integracji, o czym świadczyć może fakt, iż wniosek został jedynie zamrożony, a nie wycofany, pomimo licznych, negatywnych komentarzy ze strony ugrupowań eurosceptycznych ${ }^{37}$.

Widać zatem wyraźnie, iż procesy decyzyjne uzależnione są od szeregu uwarunkowań, zarówno wewnętrznych jak i zewnętrznych. Ich powodzenie związane jest z umiejętnością znalezienia właściwego rozwiązania, optymalnego i akceptowalne dla każdej z zainteresowanych stron. Nie zawsze zatem koncepcje polityczne są możliwe do zrealizowania w praktyce. Czas pokarze, która z dróg do integracji ze Wspólnotą była odpowiedniejsza i czy w przyszłości nie okaże się, iż oba państwa, pomimo wyboru odmiennych form współpracy będą w równym stopniu zintegrowane z Unią Europejską.

\section{Zusammenfassung}

\section{ÖSTERREICH UND DIE SCHWEIZ GEGENÜBER DER SCHAFFUNG DES GEMEINSAMEN EUROPÄISCHEN MARKTES. EINE VERGLEICHENDE ANALYSE}

In diesem Artikel wurde untersucht, in einer vergleichenden Perspektive, die Politik der zwei in vieler Hinsicht sehr ähnlichen, neutralen Staaten, gegenüber der EG, mit besonderem Schwerpunkt auf der Zeit nach der Unterzeichnung der Einheitlichen Europäischen Akte. Analysiert wurden die wichtigsten externen und inneren Determinanten, die der Wahl einer spezifischen Integrationswege bestimmten. Trotz der konvergierenden politischen und wirtschaftlichen Ziele, die Entscheidungen beider Staaten waren durch unterschiedliche Bedingungen determiniert. Für Österreich die Integration war ein wichtiger Schritt, sowohl in ökonomischer- Umstrukturierung der Volkswirtschaft, die Abschaffung von Handelshemmnissen mit den wichtigsten Wirtschaftspartner, als auch politischen Hinsicht, die die Möglichkeit einer Mitendscheidung auf der europäischen Ebene bietet. Darum haben sich die Behörden für einer Lösung, die mit der Position der EG Staaten und gleichzeitig mit der sozialen Erwartungen in Österreich kohärent war, entschlossen. Im Gegensatz zu den österreichischen Regierung, die Behörden in Bern haben im viel mehr polarisierten Bedingungen gewirkt. Neutralität spielte hier eine gravierende Rolle. Es wurde auch die komplette Öffnung des Marktes und der politischen Abhängigkeit von transnationalen Institutionen befürchtet. Die Schweizer Behörden waren also gezwungen, auf die Idee der bilateralen Beziehungen zu konzentrieren, die, obwohl nicht im Einklang mit der Position der EU Staaten stand, aber weit sozialverträglicher war, und daher praktikabler.

37 Posłowie SVP kilkukrotnie zgłaszali na forum parlamentu postulaty wzywające rząd do całkowitego wycofania wniosku akcesyjnego. 